\title{
The Essential Oil of Eucalyptus grandis W. Hill ex Maiden Inhibits Microbial Growth by Inducing Membrane Damage
}

\author{
Oluwagbemiga Sewanu Soyingbe ${ }^{1}$, Adebola Oyedeji ${ }^{2}$, Albert Kortze Basson ${ }^{1}$, Andy Rowland Opoku ${ }^{{ }^{*}}$ \\ ${ }^{1}$ Department of Biochemistry and Microbiology, University of Zululand, Empangeni, South Africa \\ ${ }^{2}$ Department of Chemistry, Walter Sisulu University, Mthatha, South Africa \\ Email: 'OpokuA@unizulu.ac.za
}

Received November 27, 2012; revised January 7, 2013; accepted January 21, 2013

\begin{abstract}
Eucalyptus grandis is a medicinal plant which has been indicated by Zulu traditional healer in the treatment of respiratory tract infections, bronchial infections, asthma and cough. The investigation of the essential oil of this plant could help to verify the rationale behind the use of the plant as a cure for these illnesses. Essential oil was hydro-distilled from the fresh leaves and characterised for the chemical constituents and bioactivity. The main constituents of the oil of the $E$. grandis are $\alpha$-Pinene (29.69\%), p-Cymene (19.89\%), 1,8-cineole (12.80\%), $\alpha$-Terpineol (6.48\%), Borneol (3.48\%) and D-Limonene (3.14\%). The essential oil of E. grandis showed high scavenging of DPPH and ABTS radicals, and was actively against 13 of the 16 organisms tested with the MIC ranging from $0.625 \mathrm{mg}-5.0 \mathrm{mg} / \mathrm{ml}$; the $\mathrm{MBC}$ value ranged from $2.5 \mathrm{mg}-10 \mathrm{mg} / \mathrm{ml}$. The essential oil also inhibited the growth of 7 of the 8 antibiotic resistant bacteria tested, with MIC ranging from $5 \mathrm{mg} / \mathrm{ml}-10 \mathrm{mg} / \mathrm{ml}$. The DNA extracted from the affected microorganisms did not show any damage. However, there was an increase of released cytosolic LDH activity. We conclude that the antibacterial activity of the essential oil was exhibited through cell membrane damage rather than the damage of the DNA. It is apparent that the bioactivity of the essential oil of $E$. grandis plays an important role in the plants' use in folk medicine for the treatment of respiratory tract illnesses.
\end{abstract}

Keywords: Essential Oil; Antioxidant; Antimicrobial Activity; LDH

\section{Introduction}

Medicinal plants form a sizeable component of traditional medicine and are mainstay for about $80 \%$ of the people in developing nations [1]. The use of medicinal plants is a basic part of African culture [2] and it is one of the oldest and most diverse all over the world [3]. In South Africa indigenous African medicine is used alongside Western allopathic medicine [4], which caters for different people of different cultures. Traditional healing which makes use of local herbs is widely practised in Zululand [5]. The medicinal effect of various plants traditionally used by the Zulus to cure different ailments has been well documented [1,6-9].

E. grandis (Figure 1) belongs to the Myrtaceae family previously native to Australia. Massive planting programs have been carried out in the Republic of South Africa, Zambia and Zimbabwe. The leaves are leathery in texture, hang oblique or vertically, and are studded with glands containing a fragrant volatile oil.

"Corresponding author.
The flowers in bud are covered with a cup-like membrane (whence the name of the genus, derived from the Greek word "eucalyptus" meaning well covered), which is thrown off as lid when the flower expands. Eucalyptus trees are quick growers and many species reach great heights [10].

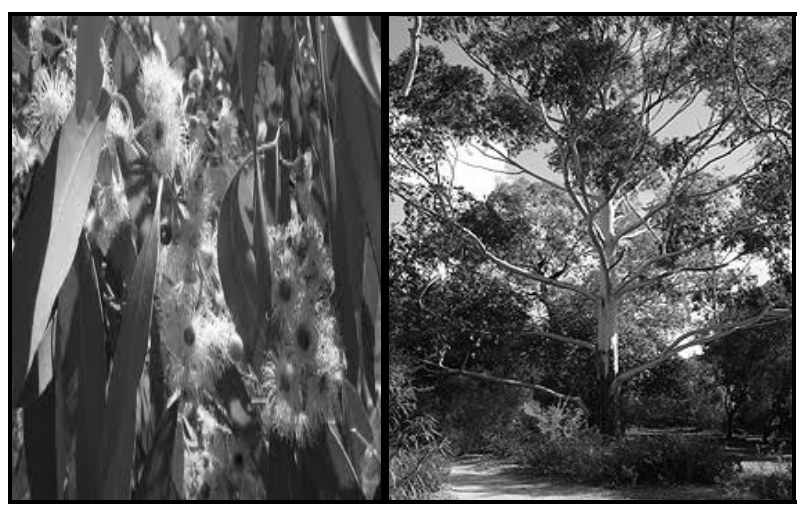

Figure 1. Eucalyptus grandis W. Hill ex Maiden (www.forestryimages.org). 
Traditional healer use Eucalyptus to treat many illnesses such as infections, colds, flu, sore throats, bronchitis, pneumonia, aching, stiffness, neuralgia [2], and as an antibiotic [11]. Vivik [12] reported its use as an antifungal agent for some skin infections.

Studies on other species from the Eucalyptus family (Eucalyptus globules and Eucalyptus citriodora) indicate $70 \%$ of their constituents to be 1,8 cineol (Eucalyptol) which has been reported to stimulate respiration, relieve coughing, helps to expel mucus, relax the respiratory muscles, and it is thus used for the management of bronchitis, asthma, catarrh, sinusitis and throat infections [13, 14]. To the best of our knowledge, little or no reports exist on the essential oil of E. grandis. Due to geographical and species differences, we investigated the chemical composition, the antioxidant and the antibacterial activity of the essential oil of the E. grandis of South Africa.

\section{Methods}

\subsection{Plant Material and Extraction of Essential Oil}

Eucaylptus grandis Hill ex Maiden was collected from the Mbakanathubana area of Eshowe, KwaZulu Natal, South Africa. The plant was taken to the Department of Botany, University of Zululand, KwaDlangezwa for identification and voucher specimens (OS.01UZ) were deposited at the University Herbarium. The leaves were picked and were subjected to more than three hours of hydrodistillation using a Clevenger-type apparatus. The essential oil so obtained was dried over anhydrous sodium sulfate, dissolved in methanol and then stored at $-4^{\circ} \mathrm{C}$ until required.

\subsection{GC-MS}

Gas Chromatography/Mass Spectrometer (GC/MS) of the essential oils was carried out using an Agilent Gas Chromatography (7890A) equipped with a capillary column (Agilent $19091530 \mathrm{~m} \times 250 \mu \mathrm{m} \times 0.25 \mu \mathrm{m}$ calibrated ) attached with an Agilent mass spectrometer system (5975C VL MSD with Triple Axis Detector). The oven temperature was programmed from $45^{\circ} \mathrm{C}-310^{\circ} \mathrm{C}$. Helium was used as the carrier gas at a flow rate of 5 $\mathrm{ml} / \mathrm{min}$ with a split ratio of $1: 200$. The essential oil $(1 \mu \mathrm{l})$ was diluted in hexane and $0.5 \mu \mathrm{l}$ of the solution was manually injected into the GC/MS. The chemical compositions of the essential oil of the fresh leave of $E$. grandis was determined according to their retention time, and spectrometric electronic libraries (WILEY NIST) Equations.

\subsection{Microorganisms}

Bacteria strains (Table 1) used in this study consisted of
Table 1. List of organisms.

\begin{tabular}{|c|c|c|}
\hline No. & Bacteria strains & Reference number \\
\hline 1. & Escherichia coli & (ATCC 8739) \\
\hline 2. & Pseudomonas aeruginosa & (ATCC 19582) \\
\hline 3. & Staphylococcus aureus & (ATCC 6538) \\
\hline 4. & Staphylococcus faecalis & (ATCC 29212) \\
\hline 5. & Bacillus cereus & (ATCC 10702) \\
\hline 6. & Bacillus pumilus & (ATCC 14884) \\
\hline 7. & Pseudomonas aeruginosa & (ATCC 7700) \\
\hline 8. & Enterobacter cloacae & (ATCC 13047) \\
\hline 9. & Klebsiella pneumoniae & (ATCC 4352) \\
\hline 10. & Serratia marcescens & (ATCC 6830) \\
\hline \multicolumn{3}{|c|}{ Environmental strains. } \\
\hline No. & Bacteria strains & Reference Strains \\
\hline 1. & Acinetobacter calcoaceticus anitratus & (CSIR) \\
\hline 2. & Bacillus subtilis & $(\mathrm{KZN})$ \\
\hline 3. & Shigella flexineri & $(\mathrm{KZN})$ \\
\hline 4. & Salmonella spp & $(\mathrm{KZN})$ \\
\hline 5. & Staphylococcus epidermidis & $(\mathrm{KZN})$ \\
\hline 6. & Enterococcus faecalis & $(\mathrm{KZN})$ \\
\hline \multicolumn{3}{|c|}{ Antibiotic resistant strains } \\
\hline No. & Antibiotic resistant strains & Reference number \\
\hline 1. & Staphylococcus aureus & (B10808) \\
\hline 2. & Staphylococcus aureus & (P12763) \\
\hline 3. & Staphylococcus aureus & (P12702) \\
\hline 4. & Staphylococcus aureus & (P12724) \\
\hline 5. & Pseudomonas aeruginosa & (T3374) \\
\hline 6. & Streptococcus viridians & (S17141) \\
\hline 7. & Klebsiella pneumoniae & (S17298) \\
\hline 8. & Klebsiella pneumoniae & (S17302) \\
\hline
\end{tabular}

reference strains identified and obtained from the Microbiology Department, University of Zululand; also included in this study were environmental strains and Antibiotic resistant strains of clinical isolates obtained from the Lancet pathology laboratory (Durban, South Africa).

The stock cultures were maintained at $4^{\circ} \mathrm{C}$ on Mueller- 
Hinton agar (Merck catalogue number 1.05435.0500).

\subsection{Antimicrobial Assay}

The antibacterial properties of the essential oils were done using the agar disk diffusion method [15]. Bacteria were grown in $20 \mathrm{ml}$ nutrient broth at $37^{\circ} \mathrm{C}$ overnight. The cultures were then diluted to the McFarland No.5 standard $\left(1.0 \times 10^{8} \mathrm{CFU} / \mathrm{ml}\right)$. Standard Petri dishes containing nutrient agar were then inoculated with the bacteria suspension $\left(1.0 \times 10^{8} \mathrm{CFU} / \mathrm{ml}\right)$. Sterile paper disks $(6 \mathrm{~mm})$ were placed on the inoculated plates and 10 $\mu \mathrm{l}$ of $10 \mathrm{mg} / \mathrm{ml}$ of the essential oils in $1 \%$ DMSO were added to the paper disk. The plates were then incubated at $37^{\circ} \mathrm{C}$ for $24 \mathrm{hrs}$ and the zone of inhibition measured. Tests were performed in triplicate and the mean values reported; Ampicillin and Neomycin were used as positive controls.

The minimum inhibitory concentration (MIC) of the essential oils was determined by the method of Eloff [16]. Nutrients broth $(50 \mu \mathrm{l})$ was added to all wells of the microtitre plate; $50 \mu \mathrm{l}$ of the essential oils $(10 \mathrm{mg} / \mathrm{ml})$ in $1 \%$ DMSO was added to the well in row $\mathrm{A}$ and then serially diluted down the rows from row A. The remaining $50 \mu \mathrm{l}$ was discarded. Bacteria culture $(50 \mu \mathrm{l})$ of McFarland standard was then added to all the wells and then incubated at $37^{\circ} \mathrm{C}$ for $24 \mathrm{hrs}$. P-iodonitrotetrazolium violet (INT) solution $(20 \mu \mathrm{l}$ of $0.2 \mathrm{mg} / \mathrm{ml})$ was then added to each well and incubated at $37^{\circ} \mathrm{C}$ for 30 mins. The MIC is the lowest concentration at which no visible microbial growth is observed. The minimum bactericidal concentration (MBC) is the lowest concentration of the sample at which inoculated bacterial strains are completely killed. This was confirmed by re-inoculating 10 $\mu l$ of each culture medium from the microtiter plates on nutrient agar plates and incubating at $37^{\circ} \mathrm{C}$ for $24 \mathrm{hrs}$. Bacteria treated with Ampicillin and Neomycin, were used as positive controls.

\subsection{Antioxidant Activity}

The essential oil was screened for antioxidant activity: The (DPPH:1.1-diphenyl-2-picrylhydrazyl; ABTS: 2,2azino-bis (3-ethylebenzthiazoline-6-sulfonic acid); NO: (nitric oxide radicals) scavenging activity, $\mathrm{Fe}^{2+}$ chelating oil was determined by the methods previously outlined $[6$, 17].

Unless otherwise stated, ascorbic acid, Trolox and BHT were used as standards. All assays were done in triplicate. The inhibitory effect of the extract on each parameter was calculated as:

$$
\% \text { Inhibition }=\left(1-A_{t} / A_{0}\right) \times 100
$$

where, $A_{0}$ is the absorbance value of the fully oxidized control and $A_{t}$ is the absorbance of the extract. The inhibitory concentration providing $50 \%$ inhibition $\left(\mathrm{IC}_{50}\right)$ was determined using statistical package Origin 6.1.

\subsection{DNA Damage (Cleavage)}

The ZR Fungal/bacterial DNA MiniPrep ${ }^{\mathrm{TM}}$ kit (Zymo Research, USA) was used for this study. Fresh bacterial cultures were treated with the essential oils (MBC concentration). Treated as well as untreated cultures were centrifuged and the pellets obtained were re-suspended in the lysis solution for $5 \mathrm{~min}$ and centrifuged $(10,000 \mathrm{~g}$ for 10 min). Fungal/Bacterial DNA Binding Buffer was then added to the suspension and centrifuged $(10,000 \mathrm{~g}$ for 10 min). The supernatant collected was added to a DNA Pre Wash Buffer and again centrifuged, after which Fungal/ Bacterial Washing Buffer was added and then centrifuged. The precipitated DNA was then eluted with the elution buffer and centrifuged. Cleavage products were analysed by agarose gel electrophoresis $(120 \mathrm{v}$ for $1 \mathrm{hr}$ ) along with standard DNA maker. The DNA was then visualized using a vilberlourmate Gel documentation system $[18,19]$.

\subsection{Lactate Dehydrogenase (LDH) Release Assay (Membrane Damage)}

The cytosolic LDH release assay was carried out according to the method previously described [20-22]. The susceptible organisms were grown and incubated with the MBC concentration of the essential oil overnight. The microbial cultures were then centrifuged $(5000 \mathrm{~g} ; 5$ mins). The supernatant $(100 \mu \mathrm{l})$ was then mixed with 100 $\mu 1$ of lactic acid dehydrogenase substrate mixture of 54 $\mathrm{mM}$ lactic acid, $0.28 \mathrm{mM}$ of phenazinemethosulfate, 0.66 $\mathrm{mM}$ p-iodonitrotetrazolium violet, and $1.3 \mathrm{mM} \mathrm{NAD}^{+}$. The pyruvate-mediated conversion of 2,4-dinitrophenylhydrazine into visible hydrazone precipitate was measured on an auto microplate reader (BiotekELx 808) at 492 $\mathrm{nm}$. The total loss of membrane integrity resulting in complete loss of cell viability was determined by lysing the cells of untreated organisms with 3\% Triton X-100 and using this sample as a positive control. The cytotoxicity in the $\mathrm{LDH}$ release test was calculated using the formula: $(\mathrm{E}-\mathrm{C}) /(\mathrm{T}-\mathrm{C}) \times 100$, where $\mathrm{E}$ is the experimental absorbance of the cell cultures, $\mathrm{C}$ is the control absorbance of the cell medium, and $\mathrm{T}$ is the absorbance corresponding to the maximal $(100 \%) \mathrm{LDH}$ release of Triton X-100 lysed cells (positive control).

\subsection{Statistical Analysis}

The mean and standard error mean of three experiments were determined. Statistical analysis of the differences between mean values obtained were calculated using Microsoft excel program, 2007 and Origin 6.0 for $\mathrm{IC}_{50}$. 


\section{Results and Discussion}

\subsection{Percentage Composition}

The percentage yield of the essential oils from the leaves of $E$. grandis was $1.78 \%$. The oil was light green in colour and with an aromatic smell. The percentage composition and the retention time of the essential oil are listed in Table 2. The major components of the oil were $\alpha$-Pinene (29.69\%), p-Cymene (19.89\%), 1,8-cineole (12.80\%), $\alpha$-Terpineol (6.48\%), Borneol (3.43\%) and D-Limonene (3.14\%). The result is similar to those reported for the other Eucalyptus species [23-26] however, while 1,8-cineole was observed to be the major component of the other species [27], we found 1,8-cineole to be only $12.8 \%$ of the components of the essential oil of fresh leaves of $E$. grandis in our study. Chemical variations within species have been attributed to factors like climatic and environmental conditions $[28,29]$.

\subsection{Antioxidant Activity}

Table 3 shows the summary of the antioxidant activities of the essential oils of E. grandis. Free radicals (which are by-products of normal biochemical processes such as mitochondrial respiration and liver oxidases and xanthine oxidase activity, atmospheric pollutants, drugs and xenobiotics metabolism [30]) have been implicated to be the causative agents of some pathophysiological conditions such as neurodegenerative diseases, autoimmune diseases, arthritis, cardiovascular diseases and even aging [31, 32]. Major damages occur when free radicals attack cellular components such as DNA, or cell membranes. Antioxidants interact with free radicals and neutralize the chain reaction before tissues and other organs are damaged. There is an increasing interest in the search for natural antioxidants [6,9]. Antioxidant activities of essential oils have been studied widely and reported. Ramzi [33] working with the essential oils of Nepetade flersiana growing in Yemen showed that the oil was able to reduce DPPH and to demonstrate a moderate antioxidant activity; the observed low antioxidant activity was associated with low content of phenolic compounds such as thymol and carvacrol in the investigated oil. The essential oils from guava stem bark were seen to be weak proton donors in DPPH reaction [34]. Kadri et al. [35] while working on the essential oil from aerial parts of Artemisia herba-alba grown in Tunisian semi-arid region postulated that antioxidant activities of the essential oil studied may be a potential source of natural antioxidants in foods and the pharmaceutical industry for the prevention and the treatment of various human diseases. Antioxidant properties of essential oils may make them a very good candidate for use as natural antioxidants and also a model for new free radical scavenging drugs. With the observed high
Table 2. Volatile constituents of the essential oil of $E$. grandis.

\begin{tabular}{|c|c|c|c|c|}
\hline Peak No. & Constituent & $\begin{array}{l}\text { Retention } \\
\text { time }\end{array}$ & $\begin{array}{c}\% \\
\text { concentration }\end{array}$ & $\mathrm{KI}^{*}$ \\
\hline 1. & $\alpha$-Pinene & 8.104 & 29.67 & 936 \\
\hline 2. & Camphene & 8.506 & 1.52 & 950 \\
\hline 3. & p-Cymene & 10.725 & 19.89 & 1025 \\
\hline 4. & D-Limonene & 10.840 & 3.14 & 1029 \\
\hline 5. & 1,8 -cineole & 10.926 & 12.80 & 1031 \\
\hline 6. & $\gamma$-Terpinene & 11.718 & 2.16 & 1060 \\
\hline 7. & Terpinolene & 12.602 & 0.35 & 1089 \\
\hline 8. & Careen & 12.906 & 0.26 & 1148 \\
\hline 9. & $\beta$-Fenchol & 13.352 & 1.21 & 1122 \\
\hline 10. & trans-pinocarveol & 13.730 & 0.60 & 1139 \\
\hline 11. & Camphor & 14.114 & 2.52 & 1146 \\
\hline 12. & Sabinyl acetate & 14.821 & 0.31 & 1166 \\
\hline 13. & Borneol & 14.906 & 3.43 & 1169 \\
\hline 14. & Terpinen-4-ol & 15.223 & 0.82 & 1177 \\
\hline 15. & $\alpha$-Terpineol & 15.625 & 6.48 & 1189 \\
\hline 16. & cis-Carveol & 16.387 & 0.43 & 1231 \\
\hline 17. & Thymol & 18.197 & 0.26 & 1290 \\
\hline 18. & Carvacrol & 18.636 & 0.37 & 1299 \\
\hline 19. & Terpinyl acetate & 19.977 & 1.60 & 1349 \\
\hline 20. & Caryophyllene & 21.903 & 0.24 & 1419 \\
\hline 21. & Alloaromadendrene & 26.127 & 1.88 & 1441 \\
\hline 22. & $\gamma$-Gurjunene & 25.536 & 0.39 & 1447 \\
\hline 23. & Viridiflorene & 22.836 & 1.51 & 1497 \\
\hline 24. & $\alpha$-calacorene & 24.878 & 0.45 & 1546 \\
\hline 25. & Spathulenol & 25.768 & 1.49 & 1578 \\
\hline 26. & caryophyllene oxide & 25.926 & 0.45 & 1583 \\
\hline 27. & $\alpha$-Eudesmol & 26.355 & 0.78 & 1632 \\
\hline 28. & cis-cadin-4-en-7-ol & 26.652 & 1.77 & 1637 \\
\hline 29. & $\begin{array}{l}\text { epoxy-allo- } \\
\text { alloaromadendrene }\end{array}$ & 26.822 & 1.05 & 1641 \\
\hline 30. & Cadine-1,4-diene & 26.822 & 0.47 & 1646 \\
\hline 31. & Amiteol & 27.139 & 0.18 & 1660 \\
\hline
\end{tabular}

*Kovats index on a DB-5 column in reference to n-alkanes (Adams 1995, 2001). MS, NIST and Wiley libraries spectra and the literature; KI, Kovats index. 
Table 3. The antioxidant activity of the essential oils of $E$. grandis.

\begin{tabular}{ccccc}
\hline \multicolumn{5}{c}{ Antioxidant activities $\mathrm{IC}_{50}(\mathrm{mg} / \mathrm{ml})$} \\
\hline & DPPH & ABTS & $\begin{array}{c}\text { Nitric } \\
\text { oxide }\end{array}$ & $\begin{array}{c}\mathrm{Fe}^{2+} \\
\text { Chelating }^{2}\end{array}$ \\
\hline $\begin{array}{c}\text { Essential oil } \\
\text { of } \text { E. grandis }\end{array}$ & 1.36 & 7.941 & 7.311 & $>10$ \\
Trolox & $>10$ & $>10$ & & \\
$\begin{array}{c}\text { Ascorbic acid } \\
\text { BHT }\end{array}$ & 1.02 & 3.94 & 5.771 & \\
Citric acid & & & $<5.00$ & \\
EDTA & & & & 8.46 \\
\hline
\end{tabular}

scavenging activity of DPPH and NO radicals, it is apparent that the essential oil of E. grandis could be a candidate for plant-derived antioxidants.

\subsection{Antimicrobial Activity}

The results (MIC and MBC values) of the antibacterial activity of the essential oil are presented in Table 4. Table 5 shows the essential oil's activity against antibiotic resistant organisms. The essential oil of E. grandis ex- hibited activity comparable to the standards and was seen to be broad spectrum in nature as it affected both Gram positive and Gram negative bacteria. It is also worth noting that the oil effectively inhibited the growth of antibiotic-resistant organisms. The oils antimicrobial activity could be attributed to the presence of compounds like 1,8 cineole, $\alpha$ and $\beta$ pinene, and limonene which have been reported [36] to have antimicrobial properties.

\subsection{DNA Cleavage}

The mechanisms of action of most plant extracts with antimicrobial activity have been poorly studied. The effect of the essential oil on the DNA and membrane of the affected microorganisms are presented in Figure 2 and Table 6, respectively. It is apparent from the DNA cleavage studies that, unlike cajanol [19] and monoterpenoidindole alkaloid [20] that was able to damage microbial DNA, the E. grandis essential oil did not affect the DNA of the organisms studied.

\subsection{LDH Activity}

The essential oil however, damaged the membrane integrity of the organism resulting in the release of the cytosolic enzyme, lactate dehyrogenase (LDH). This result

Table 4. Minimum inhibitory concentration (MIC) and minimum bactericidal concentration (MBC) of the essential oil of $E$. grandis.

\begin{tabular}{|c|c|c|c|}
\hline Bacteria strains & $\begin{array}{l}\text { MIC of essential oil of E. grandis } \\
\qquad(\mathrm{mg} / \mathrm{ml})\end{array}$ & $\begin{array}{l}\text { MIC of Ampicillin } \\
(\mathrm{mg} / \mathrm{ml})\end{array}$ & $\begin{array}{l}\text { MBC of essential oil of } E \text {. grandis } \\
\qquad(\mathrm{mg} / \mathrm{ml})\end{array}$ \\
\hline Esherichia coli (ATCC 8739) & 0.625 & 1.25 & 2.5 \\
\hline Psuedomonas aeruginosa (ATCC 19582) & 10 & 5 & 10 \\
\hline Staphylococcus aureus (ATCC 6538) & 1.25 & 2.5 & 3.25 \\
\hline Streptococcus faecalis (ATCC 29212) & 2.5 & 5 & 5.5 \\
\hline Bacillus cereus (ATCC 10702) & 0.625 & 5 & 3.25 \\
\hline Bacillus pumilus (ATCC 14884) & 0.625 & 2.5 & 3.25 \\
\hline Psuedomonas aeruginosa (ATCC 7700) & 0.625 & 5 & 4.5 \\
\hline Enterobacter cloacae (ATCC 13047) & 1.25 & 1.25 & 10 \\
\hline Klebsiella pneumonia (ATCC 10031) & 1.25 & 2.5 & 2.5 \\
\hline Serratia marcescens (ATCC 6830) & 5 & NA & 10 \\
\hline Acinetobacter calcoaceticus anitratus (CSIR) & 2.5 & NA & 2.5 \\
\hline Bacillus subtilis (KZN) & 2.5 & 0.625 & 10 \\
\hline Shigella flexineri (KZN) & 2.5 & 5 & 4.25 \\
\hline Salmonella spp.(KZN) & 5 & 5 & 5.5 \\
\hline Staphylococcus epididirmis (KZN) & 10 & 10 & $>10$ \\
\hline Enterococcus faecalis (KZN) & 2.5 & 5 & 5.25 \\
\hline
\end{tabular}

MIC values given as $\mathrm{mg} / \mathrm{ml}$ for essential oils, $\mathrm{ND}=$ not determined $\mathrm{NA}=$ not active, $\mathrm{DMSO}=$ dimethyl sulfoxide. 
Table 5. Zone of inhibition, MIC and MBC of the essential oil of E. grandis (antibiotic resistant microorganism).

\begin{tabular}{|c|c|c|c|c|}
\hline Antibiotic resistant bacteria strains & Antibiotic resistant to & Zone of inhibition (mm) & $\mathrm{MIC}(\mathrm{mg} / \mathrm{ml})$ & $\mathrm{MBC}(\mathrm{mg} / \mathrm{ml})$ \\
\hline Staphylococcus aureus $\mathrm{P} 12702$ & CIPRO: Levo Clindamycin & $19 \pm 0$ & 2.5 & 2.5 \\
\hline Staphylococcus aureus $\mathrm{P} 12763$ & CIPRO: Levo Clindamycin & $14 \pm 0.1$ & 10 & $>10$ \\
\hline Staphylococcus aureus $\mathrm{P} 12724$ & CIPRO: Levo Clindamycin & $14 \pm 0.1$ & 10 & $>10$ \\
\hline Staphylococcus aureus B10808 & Oxa:Clox, Oxa: meth, Gentamicin, Penicillin & $14 \pm 0.1$ & 10 & $>10$ \\
\hline Str. viridans $\mathrm{S} 17141$ & Oxa: meth, OxaClox & $18 \pm 0.1$ & 5 & 5.25 \\
\hline Psuedomonas aeruginosa $\mathrm{T} 3374$ & Cotrimoxazole & NA & NA & ND \\
\hline Klebsiella Spp. S 17302 & Ampicillin & $20 \pm 0$ & 2.5 & 2.5 \\
\hline Klebsiella pneumonia S 17298 & Ampicillin & $21 \pm 0.1$ & 2.5 & 5.25 \\
\hline
\end{tabular}

*Oxa: Oxacillin; Clox: Cloxacillin; Meth: Methicillin; Levo: Levofloxacin; CIPRO Ciprofloxacin. ND = Not determined NA = Not acti.

shown in Table 6 is similar to previous studies of Mirzoeva et al. [37] and Sánchez-González et al. [38] which showed that extracts of medicinal plants damaged microbial cell membranes. Essential oils target negatively charged bacterial surfaces and disrupt microbial cytoplasmic membranes, causing increased permeability of cell membranes or lysis of cell walls and loss of cellular constituents. Since penicillin- and mutation-resistant strains of microbial pathogens are on the increase, there is a need to search for new compounds (that are not penicillin based) that inhibit microbial growth. The antibacterial activity of the E. grandis' essential oil coupled to its antioxidant properties presents the oil as a good candidate for the search of therapeutic agents.

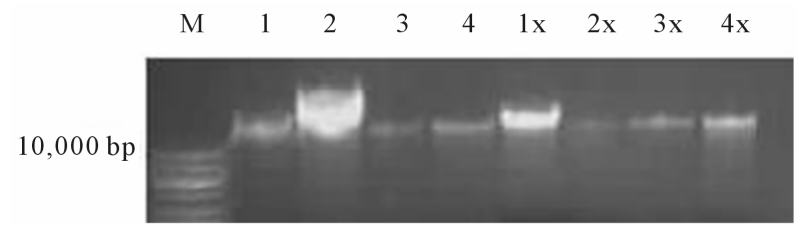

Figure 2. DNA cleavage activity of the essential oil of $E$. grandis against Esherichia coli (ATCC 8739), Bacillus pumilus (ATCC 14884), Enterobacter cloacae (ATCC 13047) and Bacillus subtilis (KZN). $M=$ DNA maker, lane 1 - 4 are untreated DNA respectively and lane $1 x-4 x$ are treated DNA respectively.

Table 6. LDH release (membrane damage) activity of the essential oil of $E$. grandis.

\begin{tabular}{cc}
\hline Bacteria & $\begin{array}{c}\text { \% LDH releases in } \\
\text { relation to Triton X-100 }\end{array}$ \\
\hline Esherichia coli (ATCC 8739) & $36.44 \%$ \\
Bacillus pumilus (ATCC 14884) & $65.91 \%$ \\
Enterobacter cloacae (ATCC 13047) & $69.40 \%$ \\
Bacillus subtilis (KZN). & $58.76 \%$ \\
\hline
\end{tabular}

\section{Conclusions}

Despite the many and varying pharmaceutical properties of E. grandis that are exploited by traditional healers, there has been little or no scientific verification of their therapeutic activities. Various respiratory pathogens that affect the respiratory tracts lead to oxidative stress which in turn triggers asthmatic attack. Substances such as allergens, pollutants, chemicals, drugs, bacteria and viruses [39], lead to the recruitment and activation of inflammatory cells which have an exceptional capacity for producing oxidants in asthmatic airways [40]. It is apparent that the search for an effective drug to manage asthma and other related complications should be directed towards agents that are antioxidant, antimicrobial, anti-inflammatory, anti-allergic, and immune-boaster in nature.

The essential oil of E. grandis contained 1,8-cineole (Eucalyptol) which has been reported to stimulate respiration and relieve coughing, helps to expel mucus, relax the respiratory muscles, and it is thus used for the management of bronchitis, asthma, catarrh, sinusitis and throat infections $[13,14]$. The observed antimicrobial and antioxidant activities in this study suggest the rational for the traditional use of $E$. grandis for therapeutic purposes.

\section{Acknowledgements}

The authors are grateful to the University of Zululand research committee for financial support.

\section{REFERENCES}

[1] J. George, M. D. Laing and S. E. Drewes, "Phytochemical Research in South Africa," Journal of Science South Africa, Vol. 97, 2001, pp. 93-105.

[2] A. Hutchings, A. H. Scott, G. Lewis and A. Cunningham, "Zulu Medicinal Plants: An Inventory," University of Natal Press, Scottsville, 1996. 
[3] B. Van Wyk and M. Wink, "Medicinal Plants of the World," Briza Publications, Queenswood, 2004.

[4] B. Van Wyk and N. Gericke, "Peoples Plants. A Guide to Useful of Southern Africa," Briza Publications, Queenswood, 2003.

[5] M. V. Gumede, "In Traditional Healers: A Medical Doctors Perspective," Skotaville Press, Johannesburg, 1989.

[6] A. R. Opoku, N. F. Maseko and S. E. Terblanche, "The in Vitro Antioxidative Activity of Some Traditional Zulu Medicinal Plants," Phytotherapy Research, Vol. 16, No. S1, 2002, pp. S51-S56. doi:10.1002/ptr.804

[7] A. Jean-Paul, F. Lorna and S. Huw, "Plant Active Components: A Resource for Antiparasitic Agents?" Trends in Parasitology, Vol. 21, No. 10, 2005, pp. 442-468.

[8] E. O. Iwalewa, L. J. Mc Gaw, V. Naidoo and J. N. Eloff, "Inflammation: The Foundation of Disease and Disorders. A Review of Phytomedicines of South African Origin Used to Treat Pain and Inflammatory Conditions," African Journal of Biotechnology, Vol. 6, No. 25, 2007, pp. 28682885.

[9] H. Bibhabasu, B. Santanu and M. Nripendranath, "Antioxidant and Free Radical Scavenging Activity of Spondiaspinnata," BMC Complementary and Alternative Medicine, Vol. 8, 2008, pp. 63.

[10] M. Jacobs, "Eucalypts for Planting," Food and Agriculture Organization of the United Nations, Rome, 1976, 398 p.

[11] D. Hopkins-Broyles, Y. Rieger, A. Grim, D. Nihill, M. Jones, R. Damiano, D. K. Warren and V. J. Fraser, "Risk Factors for Staphylococcus aureus Colonization in a Cardiac Surgery Population," American Journal of Infection Control, Vol. 32, No. 3, 2004, p. 119

doi:10.1016/j.ajic.2004.04.176

[12] K. Vivek, S. S. Bajpai and C. K. Sun, "Chemical Composition and Antifungal Activity of Essential Oil and Various Extract of Silenearmeria L.," Bioresource Technology, Vol. 99, No. 18, 2008, pp. 8903-8908. doi:10.1016/j.biortech.2008.04.060

[13] F. Sisay, L. T. Gil, W. E. Tolosana and R. López, "Eucalyptus Species Management, History, Status and Trends in Ethiopia," Proceedings from the Congress, Addis Ababa, 15-17 September 2010, pp. 62-68.

[14] F. A. Santos and V. S. Rao, "Anti Inflammatory and Antinociceptive Effects of 1,8-Cineole, a Terpenoid Oxide Present in Many Plant Essential Oils," Phytotherapy Research, Vol. 14, No. 4, 2000, pp. 240-244. doi:10.1002/1099-1573(200006)14:4<240::AID-PTR573 $>3.0 . \mathrm{CO} ; 2-\mathrm{X}$

[15] S. F. Van Vuuren and A. M. Viljoen, "A Comparative Investigation of the Antimicrobial Properties of Indigenous South African Aromatic Plants with Popular Commercially Available Essential Oils," Journal of Essential Oil Research, Vol. 18, 2006, pp. 66-71.

[16] J. N. Eloff, "A Sensitive and Quick Method to Determine the Minimal Inhibitory Concentration of Plant Extracts for Bacteria," Planta Medicine, Vol. 64, No. 8, 1998, pp. 711-713. doi:10.1055/s-2006-957563

[17] M. B. C. Simelane, O. A. Lawal, T. G. Djarova and A. R. Opoku, "In Vitro Antioxidant and Cytotoxic Activity of
Gunnera perpensa L. (Gunneraceae) from South Africa," Journal of Medicinal Plants Research, Vol. 4, No. 21, 2010, pp. 2181-2188.

[18] X. Liu, X.-J. Zhang, Y.-J. Fu, Y. G. Zu, N. Wu, L. Liang and T. Efferth, "Cajanol Inhibits the Growth of Escherichia coli and Staphylococcus aureus by Acting on Membrane and DNA Damage," Planta Medicine, Vol. 77, No. 2, 2011, pp. 158-163. doi:10.1055/s-0030-1250146

[19] M. Wu, P. Wu, H. H. Xie, G. J. Wu and X. Y. Wei, "Monoterpenoid Indole Alkaloids Mediating DNA Strand Scission from Turpinia arguta," Planta Medicine, Vol. 77, No. 3, 2011, pp. 284-286. doi:10.1055/s-0030-1250239

[20] C. Korzeniewski and D. M. Callewaert, "An EnzymeRelease Assay for Natural Cytotoxicity," Journal of Immunological Methods, Vol. 64, No. 3, 1983, pp. 313-320. doi:10.1016/0022-1759(83)90438-6

[21] V. Badovinac, V. Trajkovic and M. Mostarica-Stojkovic, "Nitric Oxide Promotes Growth and Major Histocompatibility Complex-Unrestricted Cytotoxicity of Interleukin2-Activated Rat Lymphocytes," Scandinavian Journal of Immunology, Vol. 52, No. 1, 2000, pp. 62-70. doi:10.1046/j.1365-3083.2000.00753.x

[22] V. M. Tadić, I. Jeremic, S. Dobric, A. Isakovic, I. Markovic, V. Trajkovic, D. Bojovic and I. Arsic, "Anti-Inflammatory, Gastroprotective, and Cytotoxic Effect of Sideritis scardica Extracts," Planta Medicine, Vol. 78, No. 5, 2012, pp. 415-427. doi:10.1055/s-0031-1298172

[23] A. Lucia, P. Gonzalez Audino, E. Seccacini, S. Licastro, E. Zerbra and H. Masuh, "Larvicidal Effect of Eucalyptus grandis Essential Oil and Turpentine and Their Major Component on Aedesaegypti Larvae," Journal of the American Mosquito Control Association, Vol. 23, No. 3, 2007, pp. 299-303.

doi:10.2987/8756-971X(2007)23[299:LEOEGE]2.0.CO;2

[24] I. A. Ogunwande, O. O. Nureni, A. A. Kasali and A. K. Wilfried, "Chemical Composition of the Essential Oils from the Leaves of Three Eucalyptus Species Growing in Nigeria," Journal of Essential Oil Research, Vol. 15, No. 5, 2003, pp. 297-301. doi:10.1080/10412905.2003.9698595

[25] K. Cimanga, S. Apers, T. Bruyne, S. Van Miert, N. Hermans, J. Totte, L. Pieters and A. J. Vlietinck, "Chemical Composition and Antifungal Activity of Essential Oils of Some Aromatic Medicinal Plants Growing in the Democratic Republic of Congo," Journal of Essential Oil Research, Vol. 14, No. 5, 2002, pp. 382-387. doi:10.1080/10412905.2002.9699894

[26] E. Dagne, D. Bisrat, M. Alemayehu and T. Worku, "Essential Oils of Twelve Eucalyptus Species from Ethiopia," Journal of Essential Oil Research, Vol. 12, No. 4, 2000, pp. 467-470. doi:10.1080/10412905.2000.9699567

[27] Y. C. Su, C.-L. Ho, E.-C. Wang and S.-T. Chang, "Antifungal Activities and Chemical Compositions of Essential Oils from Leaves of Four Eucalypts," Taiwan Journal of Forest Science, Vol. 21, No. 1, 2006, pp. 49-61.

[28] S. M. A. Zobayed, F. Afreen and T. Kozai, "Temperature Stress Can Alter the Photosynthetic Efficiency and Secondary Metabolite Concentrations in St. John's Wort," Plant Physiology and Biochemistry, Vol. 43, No. 10-11, 
2005, pp. 977-984. doi:10.1016/j.plaphy.2005.07.013

[29] A. Kirakosyan, E. Seymour, P. B. Kaufman, S. Warber, S. Bolling and S. C. Chang, "Antioxidant Capacity of Polyphenolic Extracts from Leaves of Crataegus laevigata and Crataegus monogyna (Hawthorn) Subjected to Drought and Cold Stress," Journal of Agricultural and Food Chemistry, Vol. 51, No. 14, 2003, pp. 3973-3976. doi:10.1021/jf030096r

[30] M. R. Saha, A. Alam, R. Akter and R. Jahangir, "In Vitro Free Radical Scavenging Activity of Ixoracoccinea L.," Bangladesh Journal of Pharmacology, Vol. 3, No. 1, 2008, pp. 90-96. doi:10.3329/bjp.v3i2.838

[31] C. Y. Hsu, Y. P. Chan and J. Chang, "Antioxidant Activity of Extract from Polygonum cuspidatum," Biological Research, Vol. 40, No. 1, 2007, pp. 13-21. doi:10.4067/S0716-97602007000100002

[32] G. Ambrosio, I. Tritto and P. Golino, "Reactive Oxygen Metabolites and Arterial Thrombosis (Review)," Cardiovascular Research, Vol. 34, No. 3, 1997, pp. 445-452. doi:10.1016/S0008-6363(97)00101-6

[33] A. M. Ramzi, "Chemical Composition, Antimicrobial and Antioxidant Activities of the Essential Oil of Nepetade flersiana Growing in Yemen," Records of Natural Products, Vol. 6, No. 2, 2011, pp. 189-193.

[34] R. T. Fasola, G. K. Oloyede and B. S. Aponjolosun, "Chemical Composition, Toxicity and Antioxidant Activities of Essential Oils of Stem Bark of Nigerian Species of Guava (Psidium guajava linn.)," EXCLI Journal, Vol. 10, No. 1, 2011, pp. 34-43.
[35] A. Kadri, B. C. Ines, Z. Zied, B. Ahmed, G. Néji, D. Mohamed and G. Radhouane, "Chemical Constituents and Antioxidant Activity of the Essential Oil from Aerial Parts of Artemisia herbaalba Grown in Tunisian Semi-Arid Region," African Journal of Biotechnology, Vol. 10, No. 15, 2011, pp. 2923-2929.

[36] G. Raju and M. Maridas, "Composition, Antifungal and Cytotoxic Activities of Essential Oils of Piper barberi Fruits," International Journal of Biological Technology, Vol. 2, No. 2, 2011, pp. 100-105.

[37] O. K. Mirzoeva, R. N. Grishanin and P. C. Calder, "Antimicrobial Action of Propolis and Some of Its Components: The Effects on Growth, Membrane Potential and Motility of Bacteria," Microbiological Research, Vol. 152, No. 3, 1997, pp. 239-246. doi:10.1016/S0944-5013(97)80034-1

[38] L. Sánchez-González, M. Vargas, C. González-Martínez, A. Chiralt and M. Cháfer, "Use of Essential Oils in Bioactive Edible Coatings: A Review," Food Engineering Reviews, Vol. 3, No. 1, 2011, pp. 1-16. doi:10.1007/s12393-010-9031-3

[39] S. J. Levine, "Bronchial Epithelial Cell-Cytokine Interactions in Airway Inflammation," Investigative Medicine, Vol. 43, 1995, pp. 241-249.

[40] S. Pinto, A. V. Rao and A. Rao, "Erythrocyte and Plasma Antioxidant in Bronchial Asthma before and after Homeopathic Treatment," Journal of Homeopathy \& Ayurvedic Medicine, Vol. 1, No. 1, 2012, p. 13. doi:10.4172/2167-1206.1000103 